Indonesian Journal of Islamic Psychology

Volume 1. Number 1, Juni 2019. (p-ISSN: 2685-1482)

website: http://e-journal.iainsalatiga.ac.id/index.php/ijip/index

\title{
Efikasi Diri dan Keterlibatan Orangtua dalam Pendidikan dengan Self Regulated Learning
}

\author{
Andreas Yudha Fery Nugroho dan Bhina Patria \\ Universitas Gadjah Mada, Yogyakarta, Indonesia \\ ayudhaferynugroho@gmail.com
}

\begin{abstract}
:
This study aimed at determining the improvement of the quality of students who refered to several factors, namely self-regulated learning, self-efficacy and parental involvement in Education using a quantitative research approach with the Self-Efficiency scale, the scale of parental involvement in education and the scale of self-regulated learning. In this study it could be said that the ability of self-efficacy and parent involvement in education were able to predict the ability of self-regulated learning. Junior high school students realized that their abilities were supported by parents who provided assistance in the learning process would make it easier to regulate teenage learning activities.
\end{abstract}

Keywords: Self Efficacy, Parents and Self Regulated Learning

\begin{abstract}
Abstrak.
Penelitian ini bertujuan untuk mengetahui peningkatan kualitas pebelajar yang merujuk pada beberapa faktor yaitu self-regulated learning, efikasi diri dan keterlibatan orangtua dalam Pendidikan dengan menggunakan pendekatan penelitian kuantitatif dengan skala Efikasi Diri, Skala keterlibatan orangtua dalam pendidikan dan Skala self regulated learning. Pada penelitian ini dapat dikatakan bahwa kemampuan efikasi diri dan Keterlibatan orangtua dalam pendidikan mampu memprediksi kemampuan self regulated learning. Remaja SMP menyadari akan kemampuan yang mereka miliki didukung oleh orangtua yang memberikan bantuan dalam proses belajar akan mempermudah dalam meregulasi kegiatan belajar remaja.
\end{abstract}

Kata Kunci: Efikasi Diri, Orang tua dan Self Regulated Learning 


\section{Pendahuluan}

Data survey Programme International Student Assessment (PISA) yang dirilis tahun 2015, pendidikan di Indonesia mengalami peningkatan dua peringkat, yaitu dari 64 ke 62 dibanding tahun 2012 (PISA, 2015). Survei ini dilakukan di 65 sampai dengan 70 negara Organization for Economic Cooperation and Development (OECD), yang melihat kemampuan membaca, sains dan matematika pada anak yang berusia 15 tahun dengan dipilih secara acak. Hasilnya, kemampuan membaca naik 10 poin, sains 32 poin dan matematika 17 poin (PISA, 2015).

Membaiknya peringkat dunia tersebut tentu masih perlu digenjot dan perbaiki. Singapura menjadi Negara di ASEAN yang menempati urutan pertama survey PISA tersebut (Putra, 2017). Singapura menjadi Negara yang mampu mengalahkan Jerman dan Belanda dalam bidang pendidikan (Putra, 2017). Indonesia tentu ingin seperti Singapura atau bahkan melebihi dan tidak mau ketinggalan dengan Negara tetangga tersebut (Putra, 2017). Oleh karena itu Indonesia harus segera membenahi sistem pendidikan yang ada saat ini dan juga peserta didik yang menjadi obyek didalamnya (Munirah, 2015).

Menurut HDI (Human Developtment Index) Indonesia pada abad ke 21 berada pada peringkat 112. Sedang Negara lain seperti Filipina, Thailand, Malaysia, Brunei, Korea Selatan dan Singapura berada pada peringkat yang tinggi, yang secara berurutan menduduki peringkat ke 85,74,58,30,31,30 dan 29 (Musyaddad, Susan, Benson, Camino \& Steiner, 2009).

Peningkatan kompetensi diri siswa tidak lepas dari peran siswa itu sendiri dalam usahanya untuk memahami potensi diri yang dimiliki, kemauan untuk berusaha menuntaskan tugas perkembangan dan yakin terhadap kemampuan diri sendiri atau yang yang disebut dengan efikasi 
diri. Efikasi diri memegang peran yang sangat penting dalam kehidupan sehari-hari, seseorang akan mampu menggunakan potensi dirinya secara optimal apabila efikasi diri mendukungnya (Smart, 2016).

Salah satu aspek efikasi diri adalah prestasi. Bandura (2007) mengemukakan efikasi diri memiliki peran besar terhadap prestasi matematika dan kemampuan menulis. Beberapa hasil penelitian menunjukan sebagai berikut: (1) penelitian Chemer et all. (2001) menemukan bahwa efikasi diri akademik berhubungan dengan prestasi dan penyesuaian diri, (secara langsung mempengaruhi prestasi akademis, sedangkan secara tidak langsung mempengaruhinya melalui harapan dan persepsi terhadap koping). (2) Pada tahun 1994 Pajares dan Miller menguji pendapat Bandura yang menyatakan bahwa efikasi diri merupakan variabel yang paling berperan untuk memprediksi prestasi remaja. Hasil penelitiannya mendukung pendapat Bandura bahwa efikasi diri merupakan variabel yang paling tinggi perannya dalam menentukan pretasi remaja (Pajares \& Miller, 1994).

Efikasi diri adalah sebuah kondisi seseorang yang mempengaruhi dan menjadi energi dalam diri yang mampu meningkatkan keberhasilan yang ingin dicapai. Efikasi diri yang tinggi membangkitkan kekuatan untuk berupaya melakukan kegiatan belajar yang lebih dalam rangka mewujudkan harapan-harapan yang dimiliki sebelumnya (Yorganci, 2017).

Efikasi yang dimiliki seseorang berperan dalam mengkondisikan diri untuk selalu berusaha dengan sungguh-sungguh karena ingin mencapai kesuksesan sebagaimana yang diinginkan. Dengan efikasi diri yang lebih tinggi juga berperan sebagai pendorong semangat diri saat melalui kesulitan dalam mencapau keberhasilan tersebut. Bila seseorang mencapai kegagalan dalam kesuksesan maka seseorang akan bertahan 
untuk tetap berusaha dengan serius agar yang akan datang dapat mencapai keberhasilan sebagaimana yang diharapkan (Hartono, 2012). Laporan tersebut memperkuat hasil survey International Educational Achivement (IEA) yang menunjukan kemampuan membaca siswa Indonesia berada pada peringkat ke 38 dari 39 negara (Musyaddad, 2013). Hasil penelitian Third Mathematics and Science Study (TIMSS) bahwa kemampuan matematika dan IPA siswa SMP Indonesia masingmasing berada pada urutan 34 dan ke 32 dari jumlah 38 negara (Musyaddad, 2013).

Data diatas menunjukan bahwa kualitas Sumber Daya Manusia (SDM) bangsa Indonesia masih rendah. Oleh karena itu perlu upaya serius untuk mengejar ketertinggalan dari Negara lain melalui proses peningkatan pendidikan yang bermutu. Dalam hal peningkatan kualitas proses pendidikan, ada sejumlah komponen yang perlu diperhatikan, yaitu komponen input, proses, output dan komponen feed back (Munirah, 2015). Komponen input menyangkut siswa, komponen proses menyangkut guru, bahan pelajaran, metode mengajar, sistem evaluasi, sarana penunjang sistem administrasi dan sebagainya, komponen output berkenaan dengan keadaan pebelajar setelah mengalami proses, dan komponen feed back terkait dengan bagaimana langkah atau upaya yang harus dilakukan setelah melihat kelemahan output (Munirah, 2015).

Komponen yang cukup penting dan harus segera dibenahi adalah komponen input atau siswa. Penelitian yang dilakukan oleh Rakhmawati (2013) mengatakan bahwa beberapa masalah yang dialami oleh siswa adalah pola belajar yang belum terstruktur, godaan hiburan yang merajalela seperti gadget membuat siswa terlena dan tidak sadar akan tugas dan kewajiban mereka sebagai pebelajar. Siswa merasa kesulitan dalam proses perencanaan, proses pelaksanaan sampai dengan proses 
evaluasi belajar secara mandiri. Siswa hendaknya memiliki kemampuan untuk belajar secara mandiri dan mampu untuk menilai proses belajar mereka. Proses belajar mandiri dengan mengedepankan perencaan, pelaksanaan dan pengevaluasian sering disebut dengan regulasi diri dalam belajar.

Dari latar belakang masalah di atas penelitian ini mengungkap mengenai tentang peningkatan kualitas pebelajar yang merujuk pada beberapa faktor yaitu self-regulated learning, efikasi diri dan keterlibatan orangtua dalam pendidikan. Penelitian ini bertujuan untuk melihat bagaimana hubungan diantara tiga faktor tersebut.

\section{Metodologi Penelitian}

Partisipan dalam penelitian ini adalah siswa-siswi Sekolah Menengah Pertama di Yogyakarta. Pemilihan partisipan dilakukan berdasarkan kriteria berikut: (1) Pelajar siswa kelas 8 Sekolah Menengah Pertama, (2) tinggal bersama dengan orangtua dirumah

Data dalam penelitian ini diambil dengan menggunakan instrumen alat ukur skala. Penggunaan skala dalam penelitian ini untuk mengukur indikator perilaku, respon dari subjek adalah jawaban yang sebenarnya dirasakan saat mengisi bukan kategori jawaban benar atau salah.

Peneliti menggunakan skala Efikasi Diri yang pernah digunakan oleh Sari (2016) dalam penelitianya tentang hubungan efikasi diri dan prokrastinasi pada mahasiswa. Pada penelitian ini Peneliti mengubah beberapa aitem untuk menyesuaikan pada subjek Remaja. Komponen dalam setiap aitem yang mengacu pada tiga dimensi Efikasi diri yaitu level, generality, dan streght. Pada skala keterlibatan orangtua dalam pendidikan siswa mengacu dari penelitian Nugroho (2012) yang telah 
dilakukan. Skala Self regulated learning disusun untuk mengukur tingkat SRL siswa. Skala yang digunakan adalah skala dari Nugroho (2012).

Penelitian ini merupakan penelitian kuantitatif sehingga diolah dengan menggunakan pendekatan statistik. Metode statistik yang digunakan pada penelitian ini yaitu teknik Multiple Regression Analysis (MRA). Teknik MRA ini termasuk jenis analisis regresi berganda linear dimana dalam persamaan regresinya mengandung unsur interaksi (perkalian dua atau lebih variabel independen). Untuk mempermudah perhitungan, peneliti menggunakan Statistikal Packages for Social Sciences (SPSS)

\section{Hasil Penelitian dan Pembahasan}

Model analisis yang digunakan dalam penelitian ini adalah teknik analisis regresi berganda, hasil analisis yang telah dilakukan terhadap data penelitian bahwa H1 yang diajukan terbukti kebenarannya. Hasil tersebut didapatkan dari hasil analisis regresi dengan nilai $\mathrm{F}$ regresi $=$ 6.902 dengan nilai R Square $0.106(p<0,05)$. Secara bersama-sama efikasi diri dan keterlibatan orangtua dapat memprediksi kemampuan selfregulated learning. Hasil penelitian ini menunjukan bahwa secara bersama-sama variabel efikasi diri dan keterlibatan orangtua dalam pendidikan dapat diprediksi kepada variabel self-regulated learning.

Pada penelitian ini dapat dikatakan bahwa kemampuan efikasi diri dan Keterlibatan orangtua dalam pendidikan mampu memprediksi kemampuan self regulated learning. Remaja SMP menyadari akan kemampuan yang mereka miliki didukung oleh orangtua yang memberikan bantuan dalam proses belajar akan mempermudah dalam meregulasi kegiatan belajar remaja. Kompetisi antar remaja disekolah memunculkan semangat belajar yang tinggi, sehingga mereka saling 
berusaha untuk menjadi yang terbaik. Peran orang tua yang vital dalam hal pemberian nasihat, membantu dalam proses pemecahan masalah belajar serta penyediaan waktu dan perhatian yang maksimal membuat remaja mampu memaksimalkan proses regulasinya. Berjalannya factor tersebut membuat remaja mampu mendapat prestasi belajar yang baik.

Hasil penelitian ini sesuai dengan Ariani \& Olvia (2009) yang mengatakan dalam penelitianya bahwa Efikasi Diri dan Keterlibatan Orangtua memiliki dampak kepada kemampuan self-regulated learning siswa SMP. Mereka sangat terbantu dengan adanya kemampuan efikasi diri untuk menumbuhkan rasa percaya bahwa dengan kemampuan yang mereka miliki mampu untuk menyelesaikan tugas tugas pendidikan. Pada penelitian ini dapat dilihat bahwa

Tanskanen \& Erola (2017) sikap terbuka siswa kepada orangtuanya akan memudahkan orangtua paham dan mengerti kesulitan yang dihadapi siswa dalam proses belajar. Orangtua akan memberikan dorongan dan bantuan dlam proses belajar. Xu, Susan, Benson, Camino \& Steiner (2009) juga mengatakan bahwa pendampingan orangtua pada masa remaja sangat diperlukan karena pada masa ini remaja mengalami peralihan pola fikir yang abstrak menjadi kongkret sehingga memunculkan sebuah pertimbangan. Dalam proses pertimbangan inilah orangtua hadir menjadi model atau contoh.

Pada variabel efikasi diri bertolak belakang dengan hasil penelitian Alberto A. Alegre (2014) yang menyebutkan bahwa ada korelasi positif antara efikasi diri dan self-regulated learning. Penelitian tersebut mengatakan bahwa semakin tinggi efikasi diri individu maka semakin tinggi juga kemampuan self-regulated learning. Wang dan Pape (2005) berpendapat juga terkait efikasi diri yang mampu memprediksi kemampuan self-regulated learning, Wang dan Pape menyebutkan 
bahwa ketika individu memiliki kepercayaan atas kemampuan yang dimilikinya dalam proses belajar akan mempermudah dalam proses penggunaan regulasi diri dalam belajar. Menurut Teori Kelekatan (attachment) pada tahap perkembangan remaja yang berusia 11-15 tahun memiliki ketergantungan kepada orangtua mereka dalam hal pengambilan keputusan. Fakta di lapangan saat ini remaja mampu menunjukan sikap independen dan mampu berfikir maupun bertindak atas dirinya sendiri.

Penelitian ini fokus kepada siswa SMP karena pada awal penulisan dikatakan bahwa masa remaja (SMP) sangat sulit diprediksi terkait kepribadian siswa, masa peralihan dari anak-anak menuju remaja menjadi problem bagi siswa atau orang tua. Beberapa siswa telah menyadari pentingnya sebuah pendidikan namun beberapa diantaranya masih acuh sehingga prestasi belajar akan berpengaruh. Siswa SMP pun ada yang memiliki anggapan bahwa mereka masih tergantung dengan kedua orangtuanya namun ada juga yang mengganggap dirinya sudah dewasa dan tidak perlu pendampingan seperti saat Sekolah Dasar (SD). Penelitian ini tentu tidak lepas dari berbagai keterbatasan, antara lain vaiabel efikasi diri yang perlu digali kembali mengapa secara parsial tidak mampu memprediksi kemampuan self-regulated learning sedangkan dalam banyak refrensi efikasi diri remaja sangat kuat dampaknya dalam hal independensi berfikir dan bertindak.

Efikasi diri dan keterlibatan orang tua secara bersama-sama memprediksi kemampuan self-regulated learning. Kontribusi kedua variabel independen tersebut sebesar 10,6\% pada variabel dependen. Keterlibatan orang tua memprediksi self-regulated learning secara parsial sebesar 2,7\%. Secara parsial efikasi diri memiliki skor yang tidak 
signifikan sehingga pada penelitian ini dianggap tidak memiliki kontribusi terhadap self-regulated learning.

\section{Simpulan}

Orang tua lebih aktif dalam memahami apa yang dibutuhkan oleh anak-anaknya. Mampu menjadi teman sekaligus sahabat yang mampu mendengarkan dan memberi solusi atas masalah yang dihadapi. Orang tua Peka terhadap perkembangan jaman sehingga mampu menyesuaikan alur pola pikir anak-anaknya. Kepada pihak sekolah mampu memberikan ruang dan waktu bagi orang tua untuk prihatin tentang anak-anaknya, sehingga dengan keluh kesah tersebut akan dibentuk sebuah komite antara sekolah dan orang tua siswa untuk membantu masalah yang dihadapi anak-anak khusunya siswa Sekolah Menengah Pertama. Kepada peneliti selanjutnya agar mampu mengembangkan variabel keterlibatan orangtua sebagai prediktor dalam kemampuan selfregulated learning. Hasil penelitian ini variabel keterlibatan orang tua dalam pendidikan pada tingkat remaja sangat dominan dibandingkan dengan variabel efikasi diri pada penelitian ini.

\section{Daftar Pustaka}

Aryahi, F. 2016. Stress Belajar: Suatu Pendekatan dan Intervensi Konseling. Edukasi Mitra Grafika. Sulawesi Tengah.

Anicama, C., Zhou. Q., Ly, J. 2017. Parental Involvement in School and Chinese American Children's Academik Skills. The Journal of Education Reseach. Vol. Iss. 0. 2017.

Azwar, S. 2015. Penyusunan Skala Psikologi. Edisi 2. Penerbit Pustaka Pelajar. Yogyakarta.

Azwar, S. 2010. Metode Penelitian. Yogyakarta: Pustaka Pelajar. 
Azwar, S. 2010. Reliabilitas dan Validitas. Yogyakarta: Pustaka Pelajar. Bandura, A. 2007. Self-efficacy in health functioning. In S. Ayers, et al. (Eds.). Cambridge handbook of psychology, health \& medicine, (2nd ed., pp. 191-193). New York: Cambridge University Press.

Biggs, J.B. 1984. Learning Strategies, student motivation patterns \& subjectively perceived success. Florida: Academic Press, Inc.

Budiningsih, A. 2004. Belajar Dan Pembelajaran. Yogyakarta: Penerbit Rinika Cipta.

Chemers, M. M., Hu, L.-T., and Garcia, B. F. 2001. Academic self-efficacy and first-year college student performance and adjustment. Journal of Educational Psychology. 93 (1): 55-64.

Chung, Y.B \& Yuen, M. 2011. The Role of Feedback in enhancing students' Self- regulation In Inviting Schools. Journal of invitational Theory and Practice. Vol 17.

Epstein, J.L., \& Salinas. K. C. 2004. Partnering with Families and Communities: Journal Educational Leadership. Vol. 61. 12-18.

Ertikan, I., Musa, S.A, Alkassim, R. S. 2016. Comparison of Convenience Sampling and Purposive Sampling. American Journal of Theoretical and Applied Statistic. Vol 5, No. 1, 2016, pp. 1-4 doi: 10.11648/j.ajtas.20160501.11

Fan, X., Chen, M. 2001. Parental Involvement and student's academic achievement: A Meta- Analysis. Educational psychology review $13,1-22$.

Ginting, B.P. 2005. Peran orang tua dalam motivasi proses pencapaian prestasi belajar di sekolah menurut siswa kelas II SMP BOPKRI II Tahun pelajaran 2004. Skripsi. FKIP. Bimbingan Konseling. Yogyakarta. Universitas Sanata Dharma. (Tidak di publikasikan) 
Hara, S.R \& Burke, D.J. 1998. Parent Involvement: The Key to Improved Student Achievement. The School Community Journal. Vol.8, No.2. Fall/Winter.

Hartono, D.R. 2012. Pengaruh sefl efficacy (efikasi diri) Terhadap tingkat kecemasan mahasiswa Kakultas Kedokteran Universitas Sebelas Maret. Skripsi Fakultas Kedokteran. (Tidak di publikasikan)

Husni, D. 2011. Prestasi Akademik Ditinjau dari Keterlibatan Orangtua dalam Pendidikan, Regulasi Emosi dan Harga Diri. Thesis tidak diterbitkan. Yogyakarta: Universitas Gajah Mada.

Hurlock, E.B. 1999. Psikologi Perkembangan: Suatu Pendekatan Sepanjang Rentang Kehidupan. Alih bahasa: Istiwidayati \& Soedjarwo. Edisi Kelima.Jakarta: Erlangga.

Segelen, I.V, Damen, Karen, V. D. 2016. "Self-reflection as a mediator between self-efficacy and well-being", Journal of Managerial Psychology, Vol. 31 Issue: 1, pp.1833, https://doi.org/10.1108/JMP-01-2013-0022

Kallio J., kauppinen T., Erola J. 2016. parental recourse, shibship size and education performance in 20 countries: Evidence for the compensation model. Cross-curtural Research 50 (5), 452-477

Lahey, B.B. 2009. Psychology: an Introduction (10 th Ed). New York Hill.

Lee, J.S \& Bowen, N.K. 2006. Parent Involvement, Cultural Capital, and the Achievement Gap among Elementary School Children. American Educational Research. Journal summer 2006, Vol.43, No. 2, pp. 193-218.

Maddrel, J. 2008. Literature Review of Self Regulated Learning. Diambil pada 10 Desember 2011 dari www.scribd.com/doc/3728825/Literature 
Nugroho, A.Y. F. 2012. Hubungan antara Keterlibatan Orangtua dan Self Regulated Learning pada Mahasiswa. Skripsi Fakultas Psikologi Universitas Sanata Dharma. Yogyakarta (Tidak di Publikasikan)

Jumana, M. 2015. Self Efficacy and Academic Performance in english. Original Scientific paper. UDK. 371.212.5 Departement of education University of Calicut.

Mestrova, J., Prochazka, J., Vaculik. M 2015. Relation between SelfEficacy, Transfotmational Leardership dan Leader Effectiveness. Journal of Advanced Managament Science Vol. 3, No. 2 June 2015.

Munirah. 2015. Sistem Pendidikan di Indonesia: Antara keinginan dan Realita. Auladuna. Vol 2. No 2 Desember 2015

Musyaddad, K. 2013. Problematika Pendidikan di Indonesia. Edu-Bio; Vol.4, tahun 2013.

Pajares, F., \& Miller, M. D. 1994. The Role of self efficacy and self concept beliefs in mathemathical problem solving. Contemporary Educational Psychology, 20, 426-443.

Purdie, N., Hottie, J., \& Douglas, G. 1996. Student conception of learning \& their use of self-regulated learning student strategies: A crossculture comparison. Journal of Education Psychology, 88, 87-100.

Putra, A. 2017. Mengkaji dan Membandingkan Kurikulum 7 Negara. File_perbandingan Kurikulum. Program Studi Pendidikan Biologi Samawa, Sumbawa Besar.

Rakhmawati. 2013. Pendidikan karakter Perseptif Pendidikan Islam. Jurnal Al Ulum Vol. 13 No 1, Juni 2013 Hal 191-214

Ratelle, Catherine. et al. 2005. Perception of Parental Involvement and Support as Prediktor of College Students' Persistence in a 
Science Curriculum. Journal of Family Psychology. Vol.19. No. 2, 286-293.

Ropp, M. 1998. A New Approach to Supporting Reflective Self Regulated Computer Learning. www.coe.uh.edu/insite/elec pub/HTML 1998/re ropp.htm

Santoso, S. 2017. Menguasai Statistik dengan SPSS 24. Kelompok Gramedia. Anggota IKAPI. Jakarta.

Sari, S.N. 2016. Hubungan efikasi diri akademik terhadap prokrastinasi akademik pada mahasiswa yang sedang menyusun skripsi. Skripsi Universitas Sanata Dharma. Tidak di publikasikan. Yogyakarta (tidak dipublikasikan)

Schunk, D. H., Pintrich, P. R., Meece, J. L. 2008. Motivation in Education, Theory, Research, and Application. ( $3^{\text {rd }}$ Ed). Upper Saddle River, New Jersey, Columbus, Ohio: Pearson Merrill Prentice Hall

Smart, L.K. 2016. Parenting Self-Efficacy in Parent of Children with Autism Spectrum Disorders. Dissertation Submitted to The Faculty of Brigham Young University. (Unpublished).

Widyastuti, Y., Rahmawati, A., Purnamaningrum, Y.E. 2009. Kesehatan Reproduksi, Yogyakarta: Fitramaya.

Wolter, C. A., Pintrich, P.R., \& Karabenick, S.A. 2003. Assessing academic self-regulated learning, Electronic Journal of Research in Education Psychology, 2(1), 1-34

$\mathrm{Xu}$, Min., Susan, N. et al. 2009. the relationship between parental involvement, self-regulated learning, and reading achievement of fifth grader: a path analysis using the ECLS-K database. Journal of Social Psychology Education. 13: 237-269. 
Yorganci, S. 2017. Investigating Students' Self Efficacy and Attitude Toward the use of Mobile Learning. Journal of Education and practice. Vol. 8, No.6, 2017

Zimmerman, B.J. 1989. A Social Cognitive view of self-regulated academic learning. Journal of Education Psychology. 81, 329-339

Zimmerman, B.J. 1990 Self Regulated Learning and Academic Achievement: An Overview. Journal of Education Psychology, 25 (1), 3-1 